POLA BUDAYA TERHADAP MAKANAN DAN GIZI, MASALAH BUDAYA TERHADAP GIZI, SOLUSI TERHADAP MASALAH DAN BUDAYA MAKANAN DAN GIZI, SERTA PENGARUH BUDAYA MAKANAN DAN GIZI

\author{
AMELIA BAKRI (70200121034) \\ KESMAS B \\ Program Studi Kesehatan Masyarakat \\ Fakultas Kedokteran dan Ilmu Kesehatan \\ Universitas Islam Negeri Alauddin Makassar
}

\title{
Pola Budaya terhadap makanan dan gizi
}

Kebudayaan adalah seluruh sistem gagasan dan ras, tindakan serta karya yang dihasilkan manusia dalam kehidupan bermasyarakat yang dijadikan miliknya dengan belajar.

Makanan atau kebiasaan makan merupakan suatu produk budaya yang berhubungan dengan sistim tingkah laku dan tindakan yang terpola (sistim sosial) dari suatu komonitas masyarakat tertentu. Sedangkan makanan yang merupakan produk pangan sangat tergantung dari faktor pertanian di daerah tersebut dan merupakan produk dari budaya juga.

Makanan sangat tergantung kepada sistem sosial kemasyarakatan dan merupakan hak asasi yang paling dasar, maka pangan/makanan harus berada di dalam kendali kebudayaan itu sendiri.

Selanjutnya dikatakan juga bahwa wujud dari budaya atau kebudayaan dapat berupa benda-benda fisik, sistim tingkah laku dan tindakan yang terpola/sistim sosial, sistim gagasan atau adat-istiadat serta kepribadian atau nilai-nilaibudaya. 


\section{Masalah Budaya terhadap makanan dan gizi}

Masalah budaya dan makanan kita ketahui dapat menyebabkan masalah gizi yang berdampak pada kesehatan tubuh manusia, sehingga perlu secara cermat untuk memberdayakan masyarakat lokal dengan kearifan dan kecerdasan lokal

Kasus lain yang berhubungan dengan sistem budaya adalah sering terjadi juga pada masyarakat di perkotaan yang mempunyai gaya hidup budaya dengan tingkat kesibukan yang tinggi karena alasan pekerjaan. Contohnya; pada ibu-ibu di daerah perkotaan yang kurang dan tidak sering menyusui bayinya dengan Air Susu Ibu (ASI) setelah melahirkan tetapi hanya diberikan formula susu bayi instant. Padahal kita tahu bahwa ASI sangat penting untuk pertumbuhan dan perkembangan fisik bayi. Selanjutnya gaya hidup mereka yang berasal dari golongan ekonomi atas (masyarakat elite kota), dalam hal makanan sering mengkonsumsi makanan yang berasal dari produk luar negeri atau makanan instant lainnya karena soal "gengsi" .

Sedangkan makanan lokal kita hanya dikonsumsi oleh mereka yang berasal dari golongan ekonomi menengah ke bawah karena ada anggapan bahwa makanan dari luar negeri kaya akan nilai gizi protein dan makanan instant lebih praktis untuk dikonsumsi sedangkan makanan lokal kita nilai gizinya lebih kepada karbohidrat.

kebiasaan dan sistim sosial masyarakat terhadap makanan seperti pola makan, tabu atau pantangan, gaya hidup, gengsi dalam mengkonsumsi jenis bahan makanan tertentu, ataupun prestise dari bahan makanan tersebut yang sering terjadi di kalangan masyarakat apabila keadaan tersebut berlangsung lama dan mereka juga belum memahami secara baik tentang pentingnya faktor gizi dalam mengkonsumsi makanan maka tidak mungkin dapat berakibat timbulnya masalah gizi atau gizi salah (Malnutrition). 


\title{
Solusi terhadap masalah dan budaya terhadap makanan dan gizi
}

\begin{abstract}
Budaya memberikan peranan dan nilai yang berbeda-beda terhadap makanan, misalnya bahan-bahan makanan tertentu oleh suatu budaya masyarakat dapat dianggap tabu atau bersifat pantangan untuk dikonsumsi karena alasan sakral tertentu atau sistim budaya yang terkait didalamnya. Disamping itu ada jenis makanan tertentu yang di nilai dari segi ekonomi maupun sosial sangat tinggi eksistensinya tetapi karena mempunyai peranan yang penting dalam hidangan makanan pada sesuatu perayaan yang berkaitan dengan kepercayaan masyarakat tertentu maka hidangan makanan itu tidak diperbolehkan untuk dikonsumsinya bagi golongan masyarakat tersebut.
\end{abstract}

Pendekatan yang paling utama adalah melalui perbaikan struktur sosial masyarakat tentang pandangan mereka terhadap bahan makanan walaupun lokal tetapi kaya akan nilai gizi. Langkah-langkah yang ditempuh seperti:

1. Perbaikan gizi keluarga dengan melakukan lomba menyiapkan hidangan makanan non beras (kasus budaya Timor),

2. Perbaikan budaya masyarakat dengan pengaruh utama gender terutama di tingkat keluarga.

3. Memperluas areal pertanian dengan menanam berbagai komoditi yang mempunyai nilai gizi tinggi sebagai bahan pangan/makanan seperti kedelai (kasus budaya Jawa).

4. Pemberian makanan tambahan yang bernilai gizi bagi anak-anak balita dan orang lanjut usia.

5. Penyuluhan gizi terpadu dan konsultasi gizi bagi masyarakat.

6. Melakukan pengkajian/penelitian dan riset untuk melihat pengaruh budaya terhadap makanan itu sendiri dengan berbagai implikasi yang terkait didalamnya.

7. Disamping itu kita harus terus melaksanakan penyuluhan gizi sebagai alternative mengatasi masalah budaya dan makanan. 


\section{Pengaruh Budaya terhadap makanan dan gizi}

Pengaruh budaya terhadap pangan atau makanan sangat tergantung kepada sistem sosial kemasyarakatan dan merupakan hak asasi yang paling dasar, maka pangan/makanan harus berada di dalam kendali kebudayaan itu sendiri. Beberapa pengaruh budaya terhadap pangan/makanan adalah: Adanya bermacam jenis menu makanan dari setiap komunitas etnis masyarakat dalam mengolah suatu jenis hidangan makanan karena perbedaan bahan dasar/adonan dalam proses pembuatan; contoh: orang Jawa ada jenis menu makanan berasal dari kedele, orang Timor jenis menu makanan lebih banyak berasal dari jagung dan orang Ambon jenis menu makanan berasal dari sagu. Demikian juga orang Sulawesi menu makanan beragam yakni berasal dari beras, jagung dan sagu. Adanya perbedaan pola makan/konsumsi/makanan pokok dari setiap suku/etnis ; Contoh : orang Timor pola makan lebih kepada jagung, orang Jawa pola makan lebih kepada beras. Adanya perbedaan cita-rasa, aroma, warna dan bentuk fisik makanan dari setiap suku-etnis; Contoh: makanan orang Padang cita rasanya pedis, orang Jawa makananya manis dan orang Timor makanannya selalu yang asin.

Dalam kehidupan sehari-hari, kita dapat dengan mudah melihat hal-hal yang berbeda sedangkan hal-hal yang sama atau bersamaan sulit atau bahkan tidak dapat diketahui seperti itulah adanya budaya dalam mengatasi masalah kesehatan dalam kehidupan kita sehari-hari semua terjadi akibat adanyapengaruhbudaya. 


\section{DAFTAR PUSTAKA}

Ibrahim, Irviani Anwar, et al. "Hubungan Sosial Budaya Dengan Kejadian Stunting Pada Balita Usia 24-59 Bulan Di Desa Bone-Bone Kecamatan Baraka Kabupaten Enrekang Tahun 2020." Al Gizzai: Public Health Nutrition Journal 1.1 (2021): 16-26.

Satrianegara, M. Fais, et al. "Cultural traditional and special rituals related to the health in Bugis Ethnics Indonesia." Gaceta Sanitaria 35 (2021): S56-S58. 